\title{
Book value, earnings, dividends, and audit quality on the value relevance of accounting information among Nigerian listed firms
}

\author{
Muhammad Yusuf Alkalia, Nasiru Liman Zuru ${ }^{\text {b* }}$ and Danjuma Safiya Kegudu ${ }^{a}$
}

${ }^{a}$ Waziri Umaru Federal Polytechnic, Birnin Kebbi, Kebbi State, Nigeria

${ }^{b}$ Univeristi Utara Malysia, Sintok Kedah Malaysia

\begin{tabular}{l}
\hline C H R O N I C L E \\
\hline Article history: \\
Received March 17, 2017 \\
Received in revised format May \\
112017 \\
Accepted July 272017 \\
Available online \\
July 272017 \\
\hline Keywords: \\
Book value \\
Earnings \\
Dividends \\
Nigeria \\
Financial reporting
\end{tabular}

\section{A B S T R A C T}

\begin{abstract}
The objective of this paper is to determine the effect of International Financial Reporting Standards (IFRS) as a new accounting reporting among Nigerian listed firms. This study uses book value, earnings and dividends to fill in the gap using a sample of 126 Nigerian listed firms in the stock market from 2009 to 2013 (pre and Post-IFRS adoption). Data was collected from Thompson Reuters, Bank scope DataStreams and annual reports. The study adopted Ohlson (1995) [Ohlson, J. (1995). Earnings, book-value, and dividends in equity valuation. Contemporary Accounting Research, 11(2), 661-687.] price model that has been frequently used in determining the quality of accounting information studies. The study finds that combined book value, earnings and dividends do not provide statistical significance effects on IFRS after adoption on the quality of accounting information. This could be possible, as dividends do not provide a significant effect in the presence of earnings. Furthermore, the audit big 4 quality provided an effect on the quality of accounting information because of IFRS adoption. Therefore, findings of this study provide additional literature on the decreasing quality of accounting information in an emerging market setting like Nigeria. The study implication is to the policy makers, regulators, and government that accounting information do not provide value relevance among Nigerian listed firms after IFRS adoption.
\end{abstract}

\section{Introduction}

Accounting research on financial market has grown since Ball and Brown (1968) produced an empirical study on stock price fluctuations and accounting information. Their seminal work inspired a string of studies presenting the relationship between stock market prices and accounting measures. After their study, more research on value relevance was conducted on the relationship between accounting information with stock price. There after several definitions of value relevance of accounting information were provided. For instance, Prather-Kinsey (2006) defined accounting information to be value relevant only when it explains stock price movement, evaluates the past and the future, and is presented without any bias. Thus, accounting

* Corresponding author. Tel.: +60163729446

E-mail address: limannasir@yahoo.com (N. Liman Zuru) 
information is value relevant once it can assist in predicting variables or can be used in a valuation model for those variables (Francis \& Schipper, 1999a,b). Hence, the ability of one or more numbers to explain variations in stock prices (Francis et al., 2006) and to also summarise valuable accounting information that may affect movements of stock prices is critical.

Scholars found the area to be relevant in predicting the quality of accounting information using disclosures reported in the financial reporting to determine the value relevance. These disclosures include balance sheet disclosures on assets and liabilities, income statements, cash flows, and earnings using the Ohlson (1995) price model (Chen et al., 2001). However, these prior studies on value relevance focused on markets in the United States and the United Kingdom (Barth et al., 1996; Barth et al., 1999; Barth, 1994; Elbakry et al., 2017).

The increasing significance of financial report for international markets led to more research investigating the value relevance of accounting information in non-developed markets outside of the United States (Amir et al., 1993; Collins et al., 1997; Graham et al., 2000), which were extended to emerging markets (Chebaane \& Othman, 2014; Chen et al., 2001; Kargin, 2013; Mironiuc et al., 2015; Umoren \& Enang, 2015; Păşcan, 2015). The results of this literature on these emerging markets provided different findings on the relevance of accounting information with respect to local accounting standards and new accounting reporting standards for different countries and sectors.

Among the questions needed to be answered about these new standards is whether accounting information increased or decreased after the adoption of International Financial Reporting Standards (IFRS). This is particularly a question of interest in Nigeria (Omokhudu \& Ibadin, 2015). Consequently, the need exists to determine empirically whether accounting information provided by firms in Nigeria has become more useful to investors in the post-IFRS period as compared to the pre-IFRS period.

Some literature exists concerning the value relevance of accounting numbers in Nigeria. For example, Abdulsallam et al. (2016), Abubakar et al. (2017), Mohammed and Lode (2016), Muhammad et al. (2015), Omokhudu and Ibadin (2015), Omokhudu and Ibadin (2015), Tanko (2012) and Umoren and Enang (2015) looked at the effect of IFRS on the value relevance of accounting information. However, the findings have been mixed and the methods have been varied. For instance, Muhammad et al. (2015) studied book value and earnings for financial institutions, Omokhudu and Ibadin (2015) and et al. (2017) looked at aggregated and disaggregated earnings and book value, assets and liabilities, Omokhudu and Ibadin (2015) considered book value, earnings, dividend and cash flows. Tanko (2012) reported on earnings managements and time loss recognition. Umoren and Enang (2015) studied earnings and book value. Mohammed and Lode (2016) investigated on assets and liabilities and Abdulsallam et al. (2016) surveyed on net income and expenses.

These studies apart from Mohammed and Lode (2016) did not consider the effect of firms' characteristics like size, leverage or audit big 4 for the value relevance studies. Also, the studies were conducted for either financial firms or non-financial firms, individually. Therefore, this study defers from all the studies conducted in Nigeria by employing audit 4, that have been neglected in value relevance studies (Chebaane $\&$ et al., 2014). Thus, the study covers all firms listed in the stock market.

\section{Nigerian Capital Market Development}

Principally, the Nigerian capital market is where corporate equities as well as long-term debts securities are traded and issued for long-term investments. The market is heavily regulated by the Nigerian Security and Exchange Commission (SEC) that is the top body regulating the Nigerian capital market. The Nigerian stock markets were opened in the early 1960s, as the Lagos Stock Exchange (LSE) as a private liability company, which was limited by guarantee as provided by the provisions of the LSE Act 1960. The LSE commenced business in 1961 with 19 listed securities that comprised 6 Federal Government Bonds, 10 Industrial loans and 3 equities (Afolabi, 2015). 
Currently, there are two main institutions in the Nigerian market: 1) the Securities and Exchange Commission (SEC), and 2) the Nigerian Stock Exchange Market (NSE). The SEC acts as the apex body and serves as the main regulatory authority in the market, while the NSE serves as the issuing houses and for the stock brokerage firms. The Nigerian capital market is like any other emerging stock market in that it protects investors from improper and unfair practices in the securities market (Oxford Business Group, 2010).

The major laws that are responsible for the capital market functioning effectively in Nigeria are 1) Investment and Security Act CAP No. 29 of 2007 (ISA), 2) The rules and regulations pursuant to the ISA, 3) Company Matters and Allied Act (CAMA), 4) the Trustee Investment Act CAP T22, LFN 2004, and 5) The Pension Act 2004. The market regulatory framework includes the SEC, regarded as the apex regulator of the stock market, the self-regulator of the market, the investments and security tribunal, and the Economic and Financial Crime Commission (EFFC).

Three types of trading are performed basically in the Nigerian stock market including 1) equities trading, 2) bond trading, and (3) exchange-traded funds (ETF). Equities trading in the Nigerian capital market comprises economic transitions of stocks are also called shares between buyers and sellers that are considered negotiable instruments that corporations issue to grant a share of the capital of the firm. Any investor who purchases a share is one of the company's owners and is entitled to profit the firms pay out in the form of dividends. There are basically two types of shareholders in Nigerian firms. Most of them are ordinary shareholders (common shares). The other holders have preferred shareholders of four types: 1) cumulative preferred shares, 2) non-cumulative preferred shares, 3) participating preferred shares, and 4) convertible shares.

Bonds listed and trading on the Nigerian stock exchange are the: 1) Federal government bonds, 2) State/Local government bonds, 3) supranational bonds and 4) corporate bonds. The Nigerian Stock Exchange defines an ETF as a fund that tracks the efficiency of a commodity or an index. They are traded like shares in the capital market and have their values derived from the commodity or the index. Investors are provided an opportunity to diversify their holdings using an ETF without having to diversify their portfolios by selecting an individual security.

\section{Literature Review}

Although several studies have cited Ohlson and the Ohlson model for their studies, using book values and earnings, very little literature used dividends as reported by Ohlson (Pirie \& Smith, 2008). With claims that IFRS has improved accounting information globally, considering the value relevance of accounting information based on book value earnings and dividends to determine if there is a change in their value relevance after the IFRS adoption is important.

The adoption of IFRS has been found to be associated with a decrease in earnings. For instance, Clarkson et al. (2011) and Goodwin and Ahmed (2006) presented evidence that the enhanced value relevance of IFRS is country specific. They reported that the combined effect of relevance of book value of equity (BVE) and earnings (NI) had changed with the adoption of IFRS with less consistency in Australia than in European countries. However, Chalmers et al. (2011) reported that earnings were more value relevant than book value under IFRS in Australia.

Studies on the value relevance of book value and earnings for different countries, firms, and standards have also been conducted. For instance, Eng et al. ( 2013) examined the value relevance of book value and earnings of firms in five Asian countries (Hong Kong, China, Singapore, Japan and Korea) that are reporting under US-GAAP, IFRS and domestic standards and listed among US American Depositary Receipts (ADRs) for the period from 2002 to 2011. For domestic samples, book value and earnings had a significant relationship with the capital market, even though book value had higher incremental value relevance content than earnings. Nevertheless, firms from the five Asian countries operated in different business 
environments, but consistent results were documented for IAS-based accounting (Singapore and Hong Kong) and domestic financial reporting (Korea, Japan, and China). Also, samples listed under ADRs had higher informative content in book value than earnings under US GAAP. In contrast, after the adoption of IFRS, earnings were found to be more value relevant than book value; however, a higher incremental value relevance of book value was reported for US GAAP users.

Kargin (2013) explored the relationship of book value (balance sheet) and earnings (income statement) with a market value under two different accounting regimes from 1998 to 2011 for Turkish firms. They observed that book value improved during the period of IFRS adoption. Furthermore, the study discovered no evidence of earnings improvements in the post-adoption period. Value relevance of accounting information improved in the post-adoption period. In contrast, Suadiye (2012) examined the significance of IFRS on the value relevance of financial reporting among the entities listed firms in the Istanbul Stock Exchange for the period from 2000 to 2009 . The study found a significant relationship between book value and earnings during the transition period.

Agostino et al. (2011) investigated the relevance of the relationship between book value and earnings among European Banks for the period from 2000 to 2006 using domestic financial reporting to the transition to IFRS. The findings of their study demonstrated that book value and earnings contained more information content in the post-adoption period of IFRS compared to pre-adoption period. Studies on book value and earnings, the relationship between earnings and operating cash flows were also reported by researchers in other different regimes. For instance, Palea (2014) examined the value relevance of different financial statements in Italian firms under GAAP and IFRS. The study showed that separate financial reports were value relevant because they both provided useful information to the capital market. Contrary to expectations, the findings indicated that reporting under IFRS had less incremental information content than Italian GAAP.

Clarkson et al. (2011) focused on the effect of IFRS adoption in Australia and Europe between book value, earnings, and market value. They reported an increase in the value relevance after the IFRS adoption in all the countries under study. Khanagha et al. (2011) reported that earnings provided higher value relevance of accounting information than book value did after IFRS adoption among Iranian firms. However, in comparison, the combined explanatory power of between the pre-and post-adoption periods of IFRS for the book value and earnings, a decline in value relevance was noticed after the reform. This means that accounting information has not improved after IFRS adoption among firms listed on the Tehran stock exchange.

Prior studies have also provided evidences on the decline value relevance of book value, earnings, and dividends (Collins et al., 1997). Barth et al. (2008) investigated the value relevance of book value and earnings relationship with stock price and returned for the IAS adopters during the period from 1994 to 2003 in 21 countries. They found an increased value relevance of book value and earnings for the price regression only. Elbakry et al. (2017) concluded that the value relevance of book value declined with an increase in earnings among German and UK firms after IFRS adoption. In contrast, they reported both book value and earnings to have increased in value relevance at the long term for the UK than German firms after IFRS adoption.

Al-Hares et al. (2012) investigated the relevance of book value, earnings, and dividends from a sample of non-financial firms listed on the Kuwait Stock Exchange (KSE). The study covers the period from 2003 to 3009. The findings of the study provided evidence of the value relevance of book value and earning after the IFRS adoption while dividends had no value relevance because of earnings in the valuation model. However, dividend when separated as individual variables showed sign of an increase in value relevance. Therefore, based on the above literature the flowing hypotheses were reported

H1: Book value, earnings, dividends, and audit quality disclosed under IFRS are more value relevant than Book value, earnings dividends, and audit quality disclosed under NGAAP among Nigerian firms. 


\section{Methodology}

The study used a sample of 126 firms listed in the Nigerian stock market over the period of 2009-2013. The year 2009-2011 was used as the pre-adoption of IFRS and 2012-2013 as the post-adoption of IFRS. The study data was collected from Thompson Reuters, bank scope DataStreams, and annual reports. The Ohlson (1995) price regression model that has been mostly adopted on value relevance study used for the study. The price regression method adopted in this study is from the studies of Burgstahler and Dichev (1997) and Collins et al. (1997).

Some researchers followed suit using similar procedures as in Francis and Schipper (1999). The dependent variable is the stock price, and book value, earnings, and dividends as independents variables. We defined all the results using incremental $\mathrm{R}^{2}$ consistent with (Bogstrand \& Larson, 2012; Francis et al., 2006; Mishari, 2016).

Therefore, the following model is drawn from the study

$$
S P_{i t}=\alpha_{0}+\beta_{1} B V_{i t}+\beta_{2} E P S_{i t}+\beta_{3} D I V_{i t}+\beta_{4} A U D_{i t}+\mu_{i t}
$$

$\mathrm{SP}_{\text {it }}=$ Stock prices per share at end of three months of the fiscal year end

$\mathrm{BV}_{\mathrm{it}}=$ Book value of equity at the end of fiscal year

$E P S_{\text {it }} \quad=$ Earning per share for firm $\mathrm{i}$ at the period $\mathrm{t}$

$D I V_{\text {it }} \quad=$ Dividend for firm $\mathrm{i}$ at the period $\mathrm{t}$

$\mathrm{AUD}_{\mathrm{it}}=$ Auditors as the dummy variable " 1 " for "Big 4" auditors and " 0 " if otherwise

$\mu_{\mathrm{it}}=$ Random error term or disturbance error

\subsection{Descriptive Statistics}

\section{Table 1}

Present descriptive statistics for book value, earnings, and dividend. The table is for the pre-and post-IFRS adoption using the stock price regressions showing 378 observations for the pre-adoption period (20092011 three years) and 252 firm observations based for the post-adoption period (2012-2013 two years).

\begin{tabular}{|c|c|c|c|c|c|c|c|c|c|c|c|c|c|c|}
\hline \multicolumn{15}{|c|}{ Panel A: Stock Price Model } \\
\hline Variable & Obs & Mean & Std. Dev. & Min & Max & Ske & Kurt & Obs & Mean & Std. Dev. & Min & Max & Skew & Kurt \\
\hline SP & 378 & 17.7114 & 61.7596 & 0.4400 & 898.00 & 0.53 & 2.69 & 252 & 21.3724 & 77.5763 & 0.4800 & 1100.00 & 0.47 & 2.58 \\
\hline BVPS & 378 & 6.1698 & 12.5686 & -16.95 & 163.79 & 0.50 & 2.77 & 252 & 7.6382 & 11.8957 & -1.51 & 77.28 & 0.24 & 2.36 \\
\hline EPS & 378 & 1.0676 & 3.4927 & -15.93 & 38.09 & -0.05 & 2.59 & 252 & 1.3752 & 3.3482 & -2.12 & 28.08 & 0.00 & 2.33 \\
\hline DIV & 378 & 0.0043 & 65.7136 & -39.86 & 95.89 & -0.15 & 2.37 & 252 & 2.0959 & 29.7554 & -30.55 & 71.90 & -0.58 & 2.93 \\
\hline
\end{tabular}

of year t, DIV = dividends for firm $i$ at the end of year t. DIV= dividends for firm $i$ at the end of the year t. All variables are deflated by the total number of outstanding shares.

The number of samples in the post-adoption period was lower than those in the pre-adoption period. The mean of BVPS was NGN6.1698 (USD0.0387) in the pre-adoption period, which was lower than the mean of BVPS in the post-adoption period NGN7.6382 (USD0.0479). The mean of EPS was NGN1.0676 (USD0.006840) in the pre-adoption period, which was lower than mean of EPS NGN1.3752 (USD0.00882) in the post-adoption period. Also, DIV mean was NGN0.0043 (USD0.00003) in the pre-adoption period, which was lower than the DIV means of NGN2.0959 (USD0.01344) in the post-adoption period. The variable AUD represents a marginal increase after IFRS adoption. The results of the descriptive statistic provided evidence of increase in value relevance after IFRS adoption. This could be possible because during the period there was an increase in stock price and market capitalisation.

\subsection{Pearson's Correlations}

Table 2 presents the Pearson's correlation for the book value earnings and dividends. The correlation matrix presented coefficients under pre-adoption of IFRS to be significantly correlated with stock prices except for 
AUD. All variables presented under IFRS adoption have a significant correlation with the stock price. This means that accounting information under IFRS has greater correlation than pre-adoption. The possibility for this increase could be attributed to NSE (2013) that reported an increase in stock price and market capitalisation during the period of 2011 to 2013 by the Nigerian firms.

Table 2

Pearson's Correlation between Book Value, Earnings, and Dividends

Panel A; Price Model

PRE-ADOPTION 2009-2011

\begin{tabular}{|c|c|c|c|c|c|}
\hline Var & SP & BVPS & EPS & DIV & AUD \\
\hline SP & 1.0000 & & & & \\
\hline BVPS & $0.1694 * * *$ & 1.0000 & & & \\
\hline EPS & $0.1392 * * *$ & -0.0973 & 1.0000 & & \\
\hline DIV & $0.1049 * *$ & -0.0967 & $-0.6608 *$ & 1.0000 & \\
\hline \multicolumn{6}{|c|}{ POST-ADOPTION 2012-2013 } \\
\hline SP & 1.0000 & & & & \\
\hline BVPS & $0.4929 * * *$ & 1.0000 & & & \\
\hline EPS & $0.1745 * * *$ & 0.0609 & 1.0000 & & \\
\hline DIV & $0.1444 * * *$ & $-0.0696 * *$ & $-0.3212 * *$ & 1.0000 & \\
\hline
\end{tabular}

Note: $* * *$ significance $1 \%$, ** significance $5 \%$, and $*$ significance $10 \%$.

\subsection{Regression results}

Table 3 provides the regression results of book value, earnings, and dividends for stock price model. The price regression model coefficients for the pooled data in the Panel A are presented by BVPS, EPS, DIV and AUD with positive coefficients $(0.0548, .2053,0.0015$ and 0.2980 at significance levels of $1 \%, 1 \%$, $10 \%$ and $5 \%$ with stock price respectively). The combined explanatory power of the variables in the polled data provided $47.74 \%$ variance with the stock price. The coefficients for all variables were positive and significant with the stock price. These indicated that Nigerian firms provided reliable information to the market and hence, reported the coefficient significance in the market value of those firms.

In addition, the variable BVPs suggested an increase in value relevance by presenting greater and positive coefficients after IFRS adoption $(0.05000$ and 0.0638 in the pre-and post-adoption periods of IFRS respectively at a significance level of $1 \%$ relationship with stock price).

Table 3

Book Value, Earnings and Dividends Hypothesis (H6)

Panel A: Price Regression Model 4

\begin{tabular}{|c|c|c|c|c|c|c|}
\hline \multirow[t]{2}{*}{ Price $^{1}$} & \multicolumn{6}{|c|}{$1 \mathrm{~A}: \beta_{1} \mathrm{BVPS}_{\mathrm{it}}+\beta_{2} \mathrm{EPS}_{\mathrm{it}}+\beta_{3} \mathrm{DIV}_{\mathrm{it}}+\beta_{4} \mathrm{AUD}_{\mathrm{it}}$} \\
\hline & $\alpha_{0}$ & $\beta_{1}$ & $\beta_{2}$ & $\beta_{2}$ & $\beta_{3}$ & $\mathrm{R}^{2}$ \\
\hline \multicolumn{7}{|c|}{ POOLED DATA 2009-2013 } \\
\hline Coef & $0.5556 * * *$ & $0.0548 * * *$ & $0.2053 * * *$ & $0.0015^{*}$ & $0.2980^{* *}$ & 0.4774 \\
\hline Tvalue & 4.44 & 4.15 & 4.71 & 1.88 & 2.43 & \\
\hline p-value & 0.000 & 0.000 & 0.000 & 0.061 & 0.015 & \\
\hline \multicolumn{7}{|c|}{ PRE-ADOPTION 2009-2011 } \\
\hline Coef & $0.6927 * * *$ & $0.0500 * * *$ & $0.1929 * * *$ & 0.0011 & $0.2616^{*}$ & 0.4098 \\
\hline Tvalue & 4.17 & 3.13 & 3.56 & 1.64 & 2.04 & \\
\hline p-value & 0.000 & 0.002 & 0.000 & 0.101 & 0.057 & \\
\hline \multicolumn{7}{|c|}{ POST-ADOPTION 2012-2013 } \\
\hline Coef & $0.3407 * *$ & $0.0638 * * *$ & $0.2174 * * *$ & $0.0046^{* * *}$ & $0.3304 *$ & 0.5822 \\
\hline Tvalue & 1.97 & 5.07 & 4.06 & 3.24 & 1.77 & \\
\hline p-value & 0.050 & 0.000 & 0.000 & 0.001 & 0.079 & \\
\hline White test & Chi $=400.49$ & & $P=0.000$ & & & \\
\hline VIF & & 1.23 & 1.23 & 1.00 & 1.00 & \\
\hline Chow test (1960) & & $\mathrm{F}=2.43$ & & & & $\mathrm{P}=0.1192$ \\
\hline \multicolumn{7}{|c|}{ 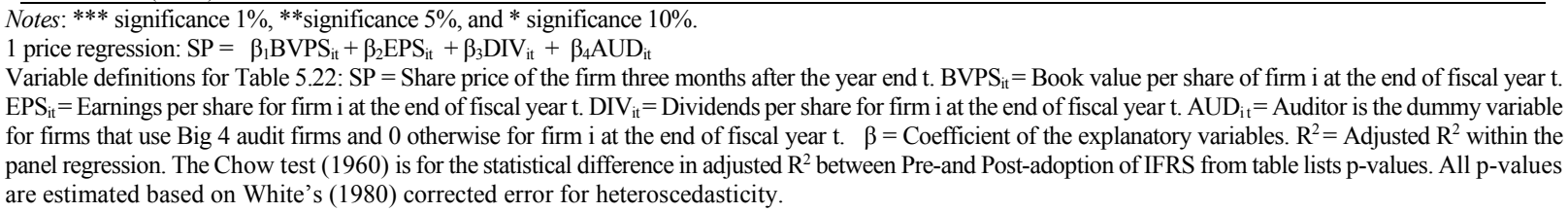 } \\
\hline
\end{tabular}


The variable EPS indicated an increase in value relevance after IFRS adoption by presenting positive coefficients of 0.001929 and 0.2174 in the pre-and post-adoption periods of IFRS respectively at significance levels of $1 \%$ each in a relationship with stock price, respectively. The variable Dividends did not support any significant relationship with stock price during the pre-adoption period, consistent with AlHares et al. (2012), in contrast, during the post-adoption had a positive coefficient of 0.00460 at a significance level of a $1 \%$ relationship with stock price. The AUD variable was also positive in the pre-and post-adoption period ( $\mathrm{pre}=0.2616$ and post $=0.3304$ ) at a significance level of a $10 \%$ relationship with stock price.

The adjusted $\mathrm{R}^{2}$ for the pre-adoption period was $40.98 \%$, which was lower than the pre-adoption period of $58.22 \%$ in explaining the power of variance with the stock price. The increased in explanatory power after IFRS adoption, signifies an increase in value relevance of accounting information. However, the Chow test (1960) for significance differences between the two periods suggested no significance differences between the two periods (value relevance, $F=2.43$ at significant level $p$-value $=0.1192$ ). Therefore, the hypothesis (H1) for more value relevance of book value, earnings, and dividend after IFRS adoption cannot be supported.

The effect of AUD big 4 presented a significant decrease when analysis was run without AUD big 4 . The full samples with AUD big 4 reported coefficients of determination $\mathrm{R}^{2}$ for the pooled data to be $47.74 \%$, pre-adoption $40.98 \%$, and post adoption $58.22 \%$ under stock price model. The results for the variable with non-Big four provided coefficients of determination $\mathrm{R}^{2}$ for the pooled data of $46.92 \%$, pre-adoption $40.50 \%$ and post-adoption $56.74 \%$ under stock price model.

\subsection{Robustness Test for Non-Financial}

The estimated coefficients provided for the sub-samples were significant like those of the full samples, preand post-adoption of IFRS in term of coefficients, significances and $\mathrm{R}^{2} \mathrm{~s}$. The result of the findings for the price regression model presented an increased in value relevance for full samples on non-financial firms (although not reported here). The stock price pre-IFRS adoption reported $\mathrm{R}^{2}$ for the full samples that were greater than the post-adoption of IFRS $\mathrm{R}^{2}$ (Pre-adoption= $40.98 \%$ versus Post-adoption $=58.22 \%$ ). However, the findings from the non-financial firms provided an increase in $\mathrm{R}^{2}$ from pre-adoption to postadoption of IFRS (Pre-adoption= $41.75 \%$ versus Post-adoption=48.25\%). The increased value relevance does not change the decision that financial institutions have any effect on the value relevance of financial reporting. The findings are consistent with (Okafor et al., 2016).

Therefore, it can be reported that the findings were robust enough. The Chow test (1960) for the sub-sample did not provide any statistical significance difference between the two $\mathrm{R}^{2} \mathrm{~s}$ for the stock price $\mathrm{n}$ model. Therefore, the conclusion for increased in value relevance could not be altered for non-financial firms, but the value relevance could not be presented.

\section{Conclusion}

This paper has determined the relative value relevance of accounting information after IFRS adoption among Nigerian firms. The central issue of the study was to determine whether accounting information had been affected by the adoption of IFRS in Nigeria among Nigerian firms. This was because the issue of the effect of IFRS on the value relevance of accounting information has still not resolved.

Using a comprehensive dataset of 126 listed firms in Nigeria, from the year 2009 to 2013, we have perform a regression analysis using stock price models that have frequently been used in determining the quality of accounting information. We have documented from the findings that, the results from the coefficients, a relative value relevance increase for book value, earnings and dividends was noticed from pre-adoption to the post-IFRS period. The increase in explanatory power has presented an increase in value relevance after IFRS adoption. However, the result from Chow test (1960) does not support any statistical significance 
increase between the two periods. This has provided evidence that there is no statistical change between the pre-and post-IFRS adoption among Nigerian firms. The study findings on the effect of AUD big 4 on the increase in value relevance was determined by the increase in explanatory power of $\mathrm{R}^{2}$ for the variables with AUD big 4 and those without AUD big 4. The results of the finding suggested an effect of AUD big 4 as a result of IFRS adoption in Nigeria.

Although, most of the studies conducted in Nigeria reported an increase in value relevance of accounting information after IFRS adoption for book value, earnings, and dividends. This study finding reported similar results of incremental value relevance, but the statistical significance difference of the explanatory power between pre-and post-adoption of IFRS cannot be reported. Therefore, other studies that reported an increased in value relevance of accounting information could not be true because they do not provide evidence of statistical significance difference between the two periods (pre-and post-IFRS adoption). This shows that accounting information provided before the IFRS adoption do not have any difference after the IFRS adoption among listed firms in Nigeria. This could perhaps be as a result of accounting reporting change immediately after financial crisis for the book value, earnings, and dividends or that the presence of dividends has an effect on the result as reported in the literature. Therefore, policy makers, regulators, government, and professionals need to look at the new accounting reporting effect on the capital market

We suggest that future study should consider the value relevance of specific variables (book value, earnings, and dividends) among listed Nigerian firm. Also, another developing country GAAP for an extended period whether there is an effect of IFRS and is statistically significant. The effect can also be used to less developed and smaller country than Nigeria to know what generalities, with regard to value relevance of accounting information as a result of IFRS adoption.

\section{References}

Abdulsallam, N., Yelwa, M., Muhammad, A., Alkali, Y., Abdul, S., \& Bala, R. (2016). Quality of accounting reporting after the IFRS adoption in Nigeria. International Journal of Business, Economics and Management, 3(11), 160-172.

Abubakar, M. Y., Abdulsallam, N., \& Alkali, M. Y. (2017). The Impact of the New Accounting Reporting Among Listed Firms in Nigerian Stock Market. Asian Journal of Social Sciences and Management Studies, 4(1), 1-9.

Afolabi, A. A. (2015). Impact of the Nigerian capital market on the economy. European Journal of Accounting Auditing and Finance Research, 3(2), 88-96.

Agostino, M., Drago, D. \& Silipo, D.B. (2011). The value relevance of IFRS in the European banking industry. Review of Quantitative Finance and Accounting, 36(3), 437-57.

Al-Hares, O. M., AbuGhazaleh, N. M., \& Haddad, A. E. (2012). Value relevance of earnings, book value and dividends in an emerging capital market: Kuwait evidence. Global Finance Journal, 23(3), 221-234. http://doi.org/10.1016/j.gfj.2012.10.006

Amir, E., Harris, T., \& Venuti, E. (1993). A comparison of the value-relevance of US versus non-US GAAP accounting measures using form 20-F reconciliations. Journal of Accounting Research, 31(3), 230-264. http://doi.org/10.2307/2491172

Elbakry, A. E., Nwachukwu, J. C., Abdou, H. A., \& Elshandidy, T. (2017). Comparative evidence on the value relevance of IFRS-based accounting information in Germany and the UK. Journal of International Accounting, Auditing and Taxation, 28, 10-30.

Ball, R., \& Brown, P. (1968). An empirical evaluation of accounting income numbers. Journal of Accounting Research, 6, 159-178.

Barth, M. E. (1994). Value accounting: Evidence from investment securities and the market valuation of banks. The Accounting Review, 69(1), 1-25. http://doi.org/10.2307/248258

Barth, M. E., Beaver, W. H., \& Landsman, W. R. (1996). Value-relevance of banks' fair value disclosures under SFAS No. 107. Accounting Review. http://doi.org/10.2307/248569

Barth, M. E., Landsman, W. R., \& Lang, M. H. (2008). International Accounting Standards and Accounting Quality. Journal of Accounting Research, 46(3), 467-498. 
Barth, M. R., Braver, W. H., Hand, J. M., \& Landsman, W. R. (1999). Accruals, cash flows, and equity values. Review of Accounting Studies, 4(3), 205-229.

Bogstrand, O., \& Larson, E. A. (2012). Have IFRS Contributed to an Increased Value-Relevance? Uppsala University. Department of Business Studies, (1606), 1-33.

Burgstahler, D., \& Dichev, I. (1997). Earnings management to avoid earnings decreases and losses. Journal of Accounting and Economics, 24, 99-126.

Chalmers, K., Clinch, G., \& Godfrey, J. M. (2011). Changes in value relevance of accounting information upon IFRS adoption: Evidence from Australia. Australian Journal of Management, 36(2), 151-173. http://doi.org/10.1177/0312896211404571

Chebaane, S., \& Othman, H. Ben. (2014). The impact of IFRS adoption on value relevance of earnings and book value of equity: The case of emerging markets in African and Asian regions. Procedia Social and Behavioral Sciences, 145(November 2015), 70-80.

Chen, C. J. ., Chen, S., \& Su, X. (2001). Is accounting information value-relevant in the emerging Chinese stock market? Journal of International Accounting, Auditing and Taxation, 10(1), 1-22.

Clarkson, P., Hanna, J. D., Richardson, G. D., \& Thompson, R. (2011). The impact of IFRS adoption on the value relevance of book value and earnings. Journal of Contemporary Accounting and Economics, 7(1), 1-17. http://doi.org/10.1016/j.jcae.2011.03.001

Collins, D. W., Edward, L. M., \& Weiss, I. S. (1997). Changes in the value-relevance of earnings and book values over the past forty years. Journal of Accounting and Economics, 24(1), 39-67.

Elbakry, A. E., Jacinta, C. N., Hussein, A. A., \& Tamer, E. (2017). Comparative evidence on the value relevance of IFRS-based accounting information in Germany and the UK. Journal of International Accounting, Auditing and Taxation, 28, 10-30.

Eng, L. L., Sun, L., \& Vichitsarawong, T. (2013). The valuation properties of earnings and book values reported under IAS, domestic GAAP and U.S. GAAP: Evidence from China, Hong Kong, Japan, Korea and Singapore. Advances in Accounting, 29(2), 278-285.

Francis, J., \& Schipper, K. (1999a). Have financial statements lost their relevance? Journal of Accounting Research, (2000), 1-4. Retrieved from http://www.jstor.org/stable/2490891

Francis, J., \& Schipper, K. (1999b). Have Financial Statements Lost Their Relevance? Journal of Accounting Research, 37(2), 319-352. http://doi.org/10.2307/2491412

Francis, J., Olsson, P., \& Schipper, K. (2006). Earnings quality. Foundations and Trends in Accounting, 1(4), 259-340.

Goodwin, J., \& Ahmed, K. (2006). Longitudinal value relevance of earnings and intangible assets: Evidence from Australian firms. Journal of International Accounting, Auditing and Taxation, 15(1), 72-91. http://doi.org/10.1016/j.intaccaudtax.2006.01.005

Graham, R., King, R., \& Bailes, J. (2000). The value relevance of accounting information during a financial crisis: Thailand and the 1997 decline in the value of the baht. Journal of International Financial Management and Accounting, 11(2), 84-107. http://doi.org/10.1111/1467-646X.00057

Ohlson, J. (1995). Earnings, book-values, and dividends in equity valuation. Contemporary Accounting Research, 11(2), 661-687.

Kargin, S. (2013). The impact of IFRS on the value relevance of accounting information: Evidence from Turkish firms. International Journal of Economics and Finance, 5(4), 71-80.

Khanagha, J. B., Mohamad, S., Hassan, T., \& Sori, Z. M. (2011). The impact of reforms on the value relevance of accounting information: Evidence from Iran. African Journal of Business Management, 5(1), 96-107.

Lev, B., \& Sougiannis, T. (1996). The capitalization, amortization, and value-relevance of R\&D. Journal of Accounting and Economics, 21(1), 107-138.

Mironiuc, M., Carp, M., \& Chersan, I.-C. (2015). The Relevance of Financial Reporting on the Performance of Quoted Romanian Companies in the Context of Adopting the IFRS. Procedia Economics and Finance, 20(15), 404-413. http://doi.org/10.1016/S2212-5671(15)00090-8

Mishari, M. A. (2016). The role of audit quality in firm valuation Evidence from an emerging capital market with a joint audit requirement. International Journal of Law and Management, Vol 58(5), 575-598. 
Mohammed, Y. A., \& Lode, N. A. (2016). The value relevance of accounting disclosures among listed Nigerian firms: IFRS adoption. Iranian Journal of Management Studies (IJMS), 9(4), 707-740. http://doi.org/10.5901/mjss.2015.v6n1p409

Muhammad, M. B., Kamarul, B. B. A. M., \& Ishak, R. B. (2015). Relative and Incremental Value Relevance of Equity and Earnings in the Nigerian Financial Industry After Mandatory Adoption of International Financial Reporting Standard (IFRS). Advanced Science Letters, 21(6), 1927-1930.

Muhammad, Y. A., \& Lode, N. A. (2015). Value relevance of liabilities and non-performing loans in emerging market: IFRS adoption in Nigeria. Advanced Science Letters, 21(6), 2015-2019. http://doi.org/10.1166/asl.2015.6190

NSE. (2013). Capital market bulleting.

Ohlson, J. (1995). Earnings, book-value, and dividends in equity valuation. Contemporary Accounting Research, 11(2), 661-687.

Okafor, O. N., Anderson, M., \& Warsame, H. (2016). IFRS and value relevance: evidence based on Canadian adoption. International Journal of Managerial Finance, 12(2), 136-160. http://doi.org/10.1108/IJMF-02-2015-0033

Omokhudu, O. O., \& Ibadin, P. O. (2015). Incremental Value Relevance of Disaggregated Book Values and Disaggregated Earnings: Evidence from Nigeria. Accounting and Finance Research, 4(3), 20 30. http://doi.org/10.5430/afr.v4n3p20

Oxford Business Group. (2010). The report Nigeria 2010.

Palea, V. (2014). Are IFRS value-relevant for separate financial statements? Evidence from the Italian stock market. Journal of International Accounting, Auditing and Taxation, 23(1), 1-17. http://doi.org/10.1016/j.intaccaudtax.2014.02.002

Păşcan, I.-D. (2015). Measuring the Effects of IFRS Adoption on Accounting Quality: A Review. Procedia Economics and Finance, 32(15), 580-587. http://doi.org/10.1016/S2212-5671(15)014355

Pirie, S., \& Smith, M. (2008). Stock prices and accounting information: evidence from Malaysia. Asian Review of Accounting, 16(2), 109-133. http://doi.org/10.1108/13217340810889924

Prather-Kinsey, J. (2006). Developing countries converging with developed-country accounting standards: Evidence from South Africa and Mexico. The International Journal of Accounting, 41, 141-162.

Suadiye, G. (2012). Value Relevance of Book Value \& Earnings Under the Local GAAP and IFRS: Evidence from Turkey. Yerel Muhasebe Standartlarına ve UFRS'ye Göre Hazırlanan Kar ve Özkaynak Rakamlarının Hisse Senedi Fiyatlarına Yansıması: Türkiye Örneği., 12(3), 301-310.

Tanko, M. (2012). The Effect of International Financial Reporting Standards (IFRS) Adoption on the Performance of Firms in Nigeria. Journal of Administrative and Economic Sciences, 5(2), 133-157.

Umoren, A. O., \& Enang, E. R. (2015). IFRS Adoption and Value Relevance of Financial Statements of Nigerian Listed Banks. International Journal of Finance and Accounting, 4(1), 1-7. http://doi.org/10.5923/j.ijfa.20150401.01

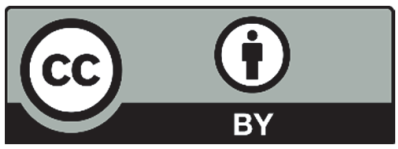

(C) 2017 by the authors; licensee Growing Science, Canada. This is an open access article distributed under the terms and conditions of the Creative Commons Attribution (CC-BY) license (http://creativecommons.org/licenses/by/4.0/). 